\title{
Generation $Y$ and Blood Donation: The Impact of Altruistic Help in a Darwiportunistic Scenario
}

\author{
Christian Scholz \\ Lehrstuhl für Betriebswirtschaftslehre, insbes. Organisation, Personal- und Informationsmanagement, Universität des Saarlandes, \\ Saarbrücken, Germany
}

\author{
Keywords \\ Blood donation - Altruistic help - Altruism . \\ Darwiportunism · Generation $Y$
}

\begin{abstract}
Summary
This article focuses on the members of Generation $Y$ and their willingness to offer voluntary (unpaid) blood donations. Using statistics from various sources, a threestage model is developed to explain blood donation behaviour especially of this generation. It consists of i) developing altruism, ii) raising the willingness to donate blood, and iii) activating actual blood donation behaviour. Members of Generation $Y$ live in a Darwinistic society. They also to some degree act opportunistically, but not in contradiction to altruism. For that reason, the article positions itself in the theoretical framework of Darwiportunism and derives practical suggestions as well as implications for research.
\end{abstract}

\section{The Challenge}

'(...) blood donation is an example of genuine altruism where the altruistic behaviour is incorporated into the self as a role' [1, p. 379]. Regardless of the debate about paid or unpaid donation of blood [2-5], there is and always will be the necessity of unpaid blood donation, and therefore always the need for people who are driven by altruistic motives. Even though this altruism calls for a very specific set of values, it seems that we do not have any problem either with blood donation in general or with the willingness of people to donate: from 2000 to

\author{
Schlüsselwörter \\ Blutspende - Altruistische Hilfe - Altruismus . \\ Darwiportunismus: Generation $Y$
}

\section{Zusammenfassung}

Dieser Artikel befasst sich mit Vertretern der Generation $Y$ und ihrer Bereitschaft zum freiwilligen (unentgeltlichen) Blutspenden. Basierend auf unterschiedlichen empirischen Quellen wird ein Drei-Stufen-Modell konzipiert, das zur Erklärung des Blutspendeverhaltens speziell in dieser Generation dient. Es besteht aus 1) Entwickeln von Altruismus, 2) Erhöhung der Spendebereitschaft und 3) Aktivierung der tatsächlichen Blutspende. Vertreter der Generation $Y$ leben in einer darwinistischen Gesellschaft. Sie handeln - und das ist kein Widerspruch zum Altruismus - zum gewissen Grad durchaus auch opportunistisch. Aus diesem Grund positioniert sich der Artikel im Darwiportunismus und macht aus diesem Erklärungsmodell heraus Vorschläge für die Praxis und die empirische Forschung.

2007 there was an increase of blood donations in Germany from 5.3 million to 6.7 million which, at 58 donors per 1,000 inhabitants, is a little above the European average [6, p. 721].

Looking at the age distribution relating to blood donations, however, one has to acknowledge that younger people are less active than older ones. According to the statistics, those in the age bracket of 36 to 55 or 45 to 55 years are the most reliable [7]. When we relate this to the date of that particular statistic, this group is the generation known as 'baby-boomers'. Looking more closely, we see an even more disturbing picture: the blood donation system is experiencing real diffi-

\section{KARGER}

Fax +497614520714

Information@Karger.de

www.karger.com (c) 2010 S. Karger GmbH, Freiburg

Accessible online at:

www.karger.com/tmh 
Table 1. Synopsis of four generations (taken from [9])

\begin{tabular}{|c|c|c|c|c|}
\hline Generation & Year of birth & General values & Work-related values & Credo \\
\hline Silent generation & $1925-1945$ & $\begin{array}{l}\text { conformism } \\
\text { maturity } \\
\text { conscientiousness } \\
\text { thrift }\end{array}$ & $\begin{array}{l}\text { obedience } \\
\text { loyalty } \\
\text { obligation } \\
\text { security (stability) }\end{array}$ & 'we must pay our dues and work hard' \\
\hline Baby boomers & 1946-1964 & $\begin{array}{l}\text { idealism } \\
\text { creativity } \\
\text { tolerance } \\
\text { freedom } \\
\text { self-fulfilment }\end{array}$ & $\begin{array}{l}\text { workaholism } \\
\text { criticism } \\
\text { innovativeness } \\
\text { advancement } \\
\text { materialism }\end{array}$ & 'if you have it, flaunt it' \\
\hline Generation X & 1965-1980 & $\begin{array}{l}\text { individualism } \\
\text { scepticism } \\
\text { flexibility } \\
\text { control } \\
\text { fun }\end{array}$ & $\begin{array}{l}\text { free agency } \\
\text { learning } \\
\text { entrepreneurship } \\
\text { materialism } \\
\text { balance }\end{array}$ & 'whatever' \\
\hline Generation Y & 1981-2001 & $\begin{array}{l}\text { collectivism } \\
\text { positivity } \\
\text { moralism } \\
\text { confidence } \\
\text { civic-mindedness }\end{array}$ & $\begin{array}{l}\text { balance } \\
\text { passion } \\
\text { learning } \\
\text { security (not stability) } \\
\text { willingness to work }\end{array}$ & 'let's make this world a better place' \\
\hline
\end{tabular}

culties. One reason is the demographical problem, which is a challenge to the whole of society. Another reason is the changing generations, since the baby-boomers display a totally different value system. In particular, we need to take a closer look at the behaviour and the value system of Generation Y, since as a group it is important in terms of size as well as influence. This Generation Y has a very specific set of values: on the one hand opportunistic perspectives on the future, on the other interests in moral issues and work-life balance.

Therefore, this paper restricts itself to just one topic: it will analyse those specific characteristics of Generation $\mathrm{Y}$ which relate on the one hand to altruism and on the other hand to attitudes connected with willingness to make blood donations. Other issues of interest will not be covered.

At this point, we must stress that this paper will not present an ethical case for or against voluntary unpaid donation. Following the classical argument of McLachlan [3], the paper will not discuss whether altruism is a particular good thing and whether we should encourage it for that reason, but it will be assumed that altruism exists and that altruism is one specific and important way to increase blood supply. Therefore, the paper deals with altruism in a positive way.

\section{Understanding the Field of Analysis}

\section{Four Generations and Four Sets of Values}

Marketing research, psychology, human resource management, behavioural studies, and demographics usually relate to the concept of generations. Consequently, a generation can be seen as a specific group of people which is defined by a specific age bracket and characterised by a distinctive set of values. These, particularly the latter, generate recognisably different behavioural patterns. The logic behind this is the underlying assumption of an external environment which shapes the character of a person: obviously a generation shaped by the paradox of Woodstock and the Vietnam War, a generation affected by the Cold War and the true meaning of the paradigm 'money makes the world go round', will develop a particular set of values. This concept, of course, has its limitations, since behavioural strategies should focus on values, which are not on the whole tied simply to a person's year of birth. This concept of generations, however, has proven to be very productive: it can be used, among other things, to define career patterns which fit specific generations.

The first generation to receive a distinctive and provocative name was Generation X, a name derived from Douglas Coupland's book 'Generation X' [8]. This generation, which is sometimes seen as 'lost', is very sceptical about the future. As a result, Generation X seeks fun and excitement in the here and now, conveying an almost apocalyptic mood and atmosphere. The definition of Generation X encouraged the definition of the two earlier generations: the 'silent generation' of World War II and the following 'baby-boomers' with all their opportunities. 'Generation Y' is the fourth generation to be endowed with a specific name. It is characterised by an optimistic view of life and overall philosophy, but is at the same time realistic and to some degree egocentric. Table 1 illustrates the basic differences between the four generations. 


\section{What Makes Generation Y Tick?}

There is no standardised way of setting age brackets to define the generations. We do, however, have a clear picture of 'what makes Gen Yer tick' [10]. On the one hand, they 'seek to explore boundaries, push limits, and experiment in the name of self-awareness, independence and self-expression' $[10$, p. 38]. They seek opportunities and are to some degree willing to work. This attitude results in various archetypes of Generation Y, which makes it difficult for industry to deal with this group, but Generation $\mathrm{Y}$ plays an important role within the economy because of its enormous size and its even more impressive capital. Generation Y 'is arguably the savviest generation ever to walk the planet' [10, p. 39]. Against this backdrop Generation $\mathrm{Y}$ is a very interesting group for companies, both in terms of valuable custom and in terms of valuable employees. This generation lives with and on the internet, is perfectly connected, and is confident about the future.

Looking in particular at the value system of this generation [11, p. 988], we can see that the top five values are (1) determination to succeed, (2) personal goals, (3) good pay, (4) selfdevelopment, (5) opportunities for training and development; at the end of the 37-item scale we see that (33) running own business, (34) sacrifice work-life balance, (35) personal sacrifices, (36) moving companies, and (37) working long hours are not so popular with the members of Generation Y. It is fair to say therefore that Generation $\mathrm{Y}$ is driven by the search for success and a career but at the same time by a refusal to sacrifice personal life to achieve them. Generation $\mathrm{Y}$ is ready to invest in the future but not at any time and not under any circumstances.

\section{Darwiportunism as a Realistic Interpretation of Generation $Y$}

To understand the motives that could bring Generation Y at least close to donating blood, one has to look at the main trends which drive and shape this generation. There are two trends [12]. The first is the dominance of Darwinism in society and economy. This logic is an analogy to the work of Charles Darwin [13]. According to him, competition between different groups within populations and between populations is based on the evolutionary paradigm of 'survival of the fittest'. The dominance of Darwinistic ideas is reflected, for example, in the concept of shareholder value, which sees the selection of companies by the capital market. As a consequence, employees no longer have guaranteed jobs. Their survival depends upon their capabilities and their strategies as well as on the success of their companies. The second trend is opportunism. This is understood as the practice of taking advantage of given chances or circumstances regardless of the consequences for others. Opportunistic people do not intend to harm other people, but they do not really care if others are suffering negative consequences from their activities. At this point it is of no interest to examine why and how these two trends emerged. Neither do we have to debate whether these trends are ethically acceptable. For our discussion, it only matters that these two trends exist as general trends. Both Darwinism and oppor- tunism hold true for companies as well as for non-profit and all other kinds of groups, including soccer teams and hospitals.

Putting both trends together, we get a phenomenon which has been called 'Darwiportunism' [14]. Company and society play in a Darwinistic way, individuals play opportunistically. Both companies and individuals know that each of them simply maximise their utility, but they also know that they only can maximise their utility together and that they are codestined. The companies try to get more efficient in order to survive which means there is no guarantee of jobs for the employees. The employees show disobedience and a kind of disloyalty towards the company. Both parties accept this, if, on the one hand, the employees do a good job as long as they work in the enterprise and if, on the other hand, the employees earn enough money. As shown by Terjesen and Frey [15, p. 68], this concept of Darwiportunism both helps us to understand Generation $\mathrm{Y}$ and heuristically empowers us to deal with it.

As regards the altruistic act of blood donation, one has to take into account the medical sector with its extreme monetary and Darwinistic tendencies as well as the opportunistic players, including the members of Generation Y. This raises the question whether in a Darwiportunistic scenario altruistic behaviour exists and how it can be developed.

\section{Altruism, Helping Behaviour, and Egoism}

Looking at altruism from a historical perspective [16], we find studies from biology and psychology which support serious arguments in favour of altruism as a genuine part of human nature. As to what constitutes human nature, there are various types of answers, which either go back to the disputable (descriptive) conundrum of whether humans are basically good or to the less disputed (normative) idea that humans should be good and take altruistic care of others.

What is striking is the immediate connection of the history of the biological studies of altruism with the oft-cited works of Charles Darwin. This means we have to look at a process labelled 'the natural selection of altruism' [17]. Given the logic of Darwiportunism, here in particular the connection between altruism and opportunism will be of interest. It has been discussed already by Dawkins [18]. His theory of the Selfish Gene proves that individual entities of a group have to act to some degree in an altruistic way in order to care for survival of the whole group. This altruistic behaviour, in order to guarantee the survival of a whole population - and thus of humankind - within the evolutionary process, is based on fundamental genes, egoistic by nature. Thus, it is essential for an individual to act altruistically within the group because of its egoistic intention to survive. Therefore, there is also a helping connection between altruism and egoism.

For the analysis of altruism and blood donation it is important to look at this connection between altruism and egoism. Both altruism and egoism are behavioural patterns, which connect a trigger with a specific action. Batson and Coke, who 


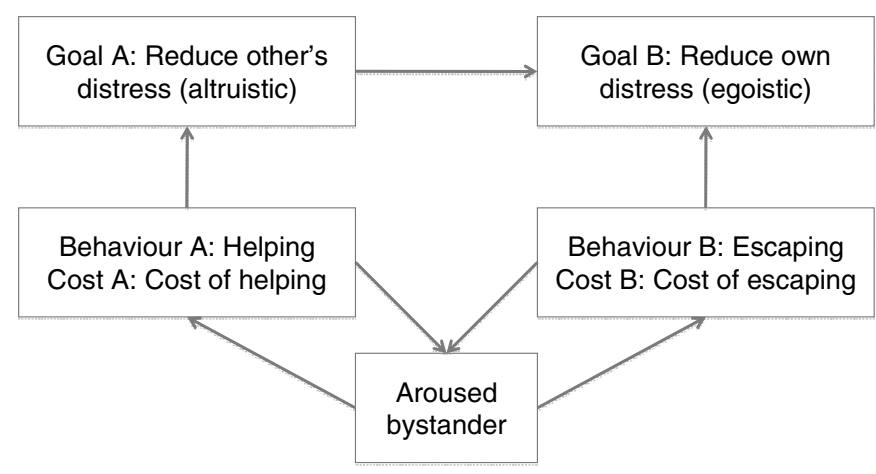

Fig. 1. Model of egoistic and altruistic motivation [taken from 19].

deal with helping behaviour and focus their discussion on that topic, see a clear difference: 'Egoistically-motivated helping is directed toward the end-state goal of increasing the helper's own welfare. (...) Altruistically-motivated helping is directed toward the end-state goal of increasing the other's welfare' [19, p. 171]. It is important that, according to this logic, it is the end-state goal, and not the behaviour that makes the difference between altruism and egoism, as can be seen in figure 1 .

The focus of interest is the arrow that leads from goal A to goal B. It suggests that even true altruism has some proportion of egoism connected to it. Thus, help can be seen as a means of helping oneself. Following this argument, donating blood could be part of the lifestyle even of Generation Y. This, however, leaves the question unanswered of where the barriers to blood donation come from. An empirical analysis in Australia showed that the decision to donate blood is a complex one and that individuals do not donate blood for purely altruistic reasons [20]: The authors '.. suggest that donation is a rational response to incentives based on reciprocity and the reinforcement of social norms in an overlapping generations model' [20, p. 501].

\section{Elements for a Theoretical Model}

There are no really conclusive data available for the topic under discussion. Therefore, we will use other data as a proxy indicator to create a framework which will suggest certain themes and lead, as we hope, to future research. Some articles, however, do have a very particular focus, even if it does not translate into the typical Generation Y framework. For instance, a survey conducted among military personnel from Israel [21] found that the approval of the supervisor who asked for volunteers to donate blood was the most important driver. Although this may hold true for the armed forces, it may not be applicable to the altruism debate in terms of Generation Y. Therefore, even though there is a lot of solid empirical research, only a little fits the topic directly or indirectly. In the following, these observations will be combined in a small hypothetical model which consists of these three steps: i) the development of altruism, ii) the chance to increase the intention to donate blood, and finally iii) the activation of behaviour.

\section{Developing Altruism Through Volunteerism}

There is a lot of literature about the factors influencing the development of altruism [22, 23]. There are, however, only two dominant drivers: the logic of volunteerism and the contextual logic of the development stage (e.g. welfare stage) of the group under consideration. Volunteerism is to be understood as the readiness to engage in community work and other activities. Even though there could be many motives for that, one of them is usually the idea of improving one's own well-being by improving the well-being of others. For the purpose of our discussion it is also important that volunteerism looks at people as spenders of time, and not (only) as spenders of money [24]. The degree of this volunteerism depends, however, on the characteristics of certain generations.

For an understanding of the specifics of volunteerism in certain generations, the study by Reisenwitz and Iyer [25] is helpful. The authors investigated differences between Generation $\mathrm{X}$ and Generation $\mathrm{Y}$ in order to deduce implications for organisations and marketers. Besides internet usage, brand loyalty, work orientation and risk aversion, volunteerism was also on their research agenda. Although their hypothesis was that there might be no significant difference between generations regarding volunteerism, results showed the mean value of volunteerism in Generation X was 3.9, whereas Generation $\mathrm{Y}$ at 4.3 showed a significantly higher value [25, p. 100]; we see the level of volunteerism in Generation Y is significantly higher than in Generation X. Even though this research was not directly performed in relation to donating blood, it tells us that the members of Generation $\mathrm{Y}$ are ready for volunteerism, which means, there should also be a tendency towards donating blood, which is also a specific way of improving one's own well-being by improving the well-being of others.

\section{Developing Altruism: The Role of the Human Development Index}

The World Health Organization [26] uses for its statistics the Human Development Index (HDI), which has been created by the United Nation Development Programme. The HDI classifies nations by criteria such as education and income. It then brings this information together with blood donations on a voluntary basis and with remunerated donations. If one takes these criteria and connects them with the idea of generations, it becomes obvious that Generation Y ranks high on the HDI scale, particularly if we include money and property as a legacy to Generation Y bequeathed by the other three generations. Of course, this index deals with countries, but it gives us important information when translated to the concept of generations. First, it is more likely we can accept Generation $\mathrm{Y}$ as an HDI generation that makes much higher voluntary donations than the other generations. We see high-HDI countries with 40 donations per 1,000 population and 98\% voluntary non-remunerated donations. Conversely, low-HDI countries have 2 donations per 1,000 population and only $31 \%$ voluntary donations (but a larger family-replacement 
percentage). Second, we cannot wait for lower-HDI groups to solve our problems, since they will not do it, regardless of whether we take generations or countries as our subject.

\section{Raising the Intention Through Personal Moral Norms}

The main focus of interest is the intention to become a blood donor and the factors influencing this decision. A cross-sectional study in the Netherlands tried to find out why young people do not volunteer to give blood [27]. Among other things, the researchers analysed the connection between the intention to donate blood on the one hand and seven independent variables on the other: 'self-efficacy' described the perception that one can manage the process of blood donation; 'attitude' analysed the general feeling toward blood donation in the sense of, e.g., 'good or bad' and 'OK or frightened'. As for the values, the researchers looked into the 'subjective norms' (e.g. 'most people important to me think I should donate blood') and 'personal moral' ('I feel a moral obligation'). Finally, scales for 'affected by consequences', 'perceived knowledge', and 'true knowledge' were used.

With regard to the results [27, p. 949], we see the greatest influence coming from personal moral norms $(\mathrm{r}=0.5)$, attitude $(\mathrm{r}=0.49)$, subjective norms $(\mathrm{r}=0.36)$, and self-efficacy $(\mathrm{r}=0.35)$. The other variables showed no relevant influence. This result is important for understanding the members of Generation Y, since they are particularly driven by their attitude and their norms. Looking at blood donation as a moral obligation seems to be the only real driver that works. On the other hand, these data tell us that campaigns should neither focus on 'blood and needles' nor on trying to give too much information which nobody really wants.

\section{Raising the Intention: The Role of Risk Aversion}

Another important aspect is risk aversion: donating blood has something to do with needles, with blood, with medical institutions. Regardless of the statistical probability of the risk involved, the subjective perception of the risk and the willingness to take risks shape behaviour. Usually Gen X-ers 'have an attitude of risk avoidance and a low capacity for risks. (...) they have levels of distrust, scepticism, and possess a selfesufficient attitude' [25, p. 95]. On the other hand, Gen Y-ers see themselves more in the position of making the world a better place, which implies willingness to help. Looking again at the research from Reisenwitz and Iyer [25] described above, we see a lower degree of risk aversion in Generation Y (5.0) than in Generation X (5.2). Therefore, even if Generation Y see subjectively the same risk connected with donating blood, they may be more willing to engage in that activity.

\section{Activating Behaviour by Altruistic Advertisement}

If we look at the process chain from altruism to intention and behaviour, we must take into account the variables that influence actual behaviour of donating blood. We noted earlier that particularly for Generation Y it is definitely counter-pro- ductive to discuss issues of 'blood and needles' (the risk issues) as part of raising the intention of donating blood. This does not mean that risks should be concealed and people uninformed. The risk issues should just not be part of the advertising campaigns. But what can be done to transform the intention to donate blood into the actual behaviour of donating blood? Given the title of this paper, the answer seems to be obvious: if Generation Y is at least partially driven by altruistic motives and if one responds at least partially to altruistic stimuli, the advertisement campaign should focus largely on altruistic motives.

Empirical data show that this is in fact a promising strategy: Windley [28] ran several experimental studies dealing with the issue of how to persuade young people actually to donate blood. In doing so, she compared the reaction to altruistic advertisements such as 'Blood donors hold a special place in my heart' with social (pressure) norms such as 'It takes us all!'. Her main message was: with regard to these kinds of advertisements, both (prior) non-donors and (prior) donors rated altruistic advertisements much higher than those that focus on social norms. Therefore, with regard to Generation $\mathrm{Y}$, advertisement campaigns need to focus strictly on altruistic aspects in order to activate behaviour.

\section{Activating Behaviour by Avoiding Crowding-Out}

Of course, increasing the system of paid donations could be one alternative. It has been proven, however, that this will reduce the number of altruistic blood donations: Png [29] measured this crowding-out effect and found that a $1 \%$ increase in incentivised blood collection is associated with a $0.55-0.71 \%$ reduction in voluntary donations. Turning this empirical observation of crowding-out into realistic recommendations, we might look into totally separate systems with totally separate incentives and markets.

The controversy about payment for blood is also discussed by Buyx [30]. Against the backdrop of the described crowding-out effects and ethical aspects, she drafts a compromise of different incentives. These non-cash incentives range from tokens of appreciation like medals or certificates to goods and gifts like t-shirts or vouchers for restaurants [30, p. 337].

\section{Putting the Model Together}

When we put i) developing altruism, ii) raising the intention, and iii) activating behaviour together, we get a stage model for voluntary blood donation, which deals in particular with Generation Y (fig. 2).

This model can be used in three different ways. As a theoretical model, it describes reality. As a starting-point for empirical research, it defines specific hypotheses to be tested. As a practical tool, it gives us some information on how to increase voluntary blood donations, particularly from Generation $\mathrm{Y}$. 


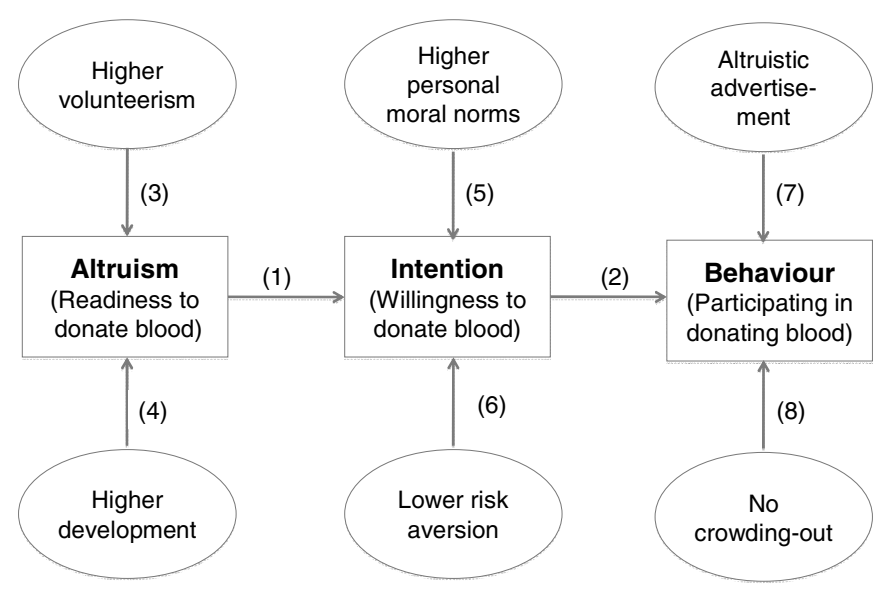

Fig. 2. The three-stage model of blood donation for Generation Y.

\section{Theoretical Description}

When interpreting the empirical data which are available, it is important to note the difference between the three stages in the model:

The first stage describes how altruism develops and whether a person is ready to donate blood. Both voluntarism and the development of altruism play a positive role for the members of Generation Y since they rank high on these factors compared with other generations. This leads to a rather positive situation because the attitude of Generation $\mathrm{Y}$ is to help improve the well-being of oneself by improving the wellbeing of others (volunteerism). In addition to that, Generation $\mathrm{Y}$ shows the characteristics of a high-HDI population that strengthen the willingness to donate blood, too. Therefore, the first stage describes readiness in the sense of basic propensity towards donating blood. Taking the analogy from jogging, readiness refers to fitness in the sense that one is capable at all of running.

The second stage has a different focus and tells us if and how the basic intention transforms itself in the willingness to go further and to donate blood. Regarding Generation Y, there are two drivers, one in favour and one against. As regards the positive driver, Generation $\mathrm{Y}$ is moved particularly by personal moral norms. They consider blood donation makes sense. On the other hand, however, the tendency to risk awareness pushes the issue in the right direction. As regards risk awareness it looks as if Generation $\mathrm{Y}$ is responsive to feeling risks, but to a lesser degree than Generation X. As regards the second stage of the model, in the same analogy, willingness refers to the question whether a person, even if he or she can run, really wants to put on their shoes on and start to run.

The real challenge is to achieve the third stage, which is to generate action. This third step is difficult because it does not deal with the intrinsic characteristics of Generation Y itself. Again, we see two main factors, one in favour and one working the other way. It looks as if the final push comes from a specific type of advertising: it should not emphasise social norm, but rather focus on altruistic motives. This means we can activate the motives from the first stage. This process refers to the argument put forward by Healy [31]. According to him, altruism is really a phenomenon created as a social construction. Altruism therefore does not constitute a specific set of unselfish values. Rather, people and society talk about something to be labelled altruism and create it through that communication. Healy concedes the necessity of a market mechanism. This brings us to the crowding-out effects in the interplay of paid donations and altruistic donations. In the same analogy from jogging, behaviour refers to whether one starts to run, which could depend upon the telephone ringing, bad weather, or a TV programme.

At this point we know that the process of activating Generation $\mathrm{Y}$ is a complex process. Also, it is important to know that we do not have to distinguish between altruistic and opportunistic motives, since these motives are connected and can be activated together.

\section{Testable Hypotheses}

The three-stage model can also be used to generate hypotheses which could be tested empirically. There are eight groups of hypotheses.

1) Altruism is positively correlated with the intention to give blood.

2) Intention to give blood and actually donating blood are positively correlated.

3a) Members of Generation Y have a higher volunteerism than the other generations.

3b)High volunteerism is positively correlated with altruism.

4a) Members of Generation Y have a higher HDI than members of other generations.

4b)HDI and altruism are positively correlated.

5a) Members of Generation Y have higher personal moral norms than other groups.

5b)Higher personal norms and intention to donate blood are positively correlated.

6a) Members of Generation Y have a lower risk aversion than other groups.

6b)Lower risk aversion and intention to donate blood are positively correlated.

7) For Generation $Y$, advertisement campaigns that focus on altruistic messages in order to increase blood donations are more effective than alternative advertisement campaigns.

8) For Generation Y, paid donation systems should be run totally independently in order to increase blood donations.

Owing to hypotheses 2), 7), and 8), this empirical test can only be performed in a setting which includes real blood donations.

\section{Practical Suggestions}

Using it as a practical tool, we know that we can count on volunteerism in Generation Y, as long as it is connected with 
feeling good. From the HDI discussion above, we know the positive impact of a high development culture for voluntary donations. These two statements tell us where to look for donors. The same holds true for moral norms and risk aversion, but with the additional recommendation that the communication should include these aspects. This is even truer for the suggested advertisement campaigns that should explicitly focus on altruistic motives.

In combination with Generation $\mathrm{Y}$ it is important to note that altruism is not just a hidden variable which influences attitudes and behaviour. Altruism is the core of the communication, regardless of whether we see it as a given value or as socially constructed. 'Donating blood voluntarily' is to be seen as part of the lifestyle of Generation $\mathrm{Y}$ and the relevant norms at least partially the consequences of social construction.

The second recommendation refers to the market situation, which we have to take into account. At this point, however, we do not discuss it solely in the sense of willingness to pay. 'Market' means considering alternatives for the blood donor. These alternatives could be spending time on other activities or donating blood for money. Bringing altruistic blood donations close to paid-for donations, however, would not in the case of members of Generation Y lead to a switch from altruistic blood donations to paid-for donations. It would disturb the picture of blood donation as an altruistic gift and would simply make members of Generation Y walk away and spend their time (and other resources) on other issues, such as Greenpeace, the World Wildlife Fund, or other worthy projects.

\section{Limitations and Conclusion}

In this article, a general framework for altruistic blood donation has been presented. The framework analyses the situation and helps to define strategies to increase the willingness to donate blood. In doing so and considering the body of knowledge and its deficits, the presented framework is a heuristic model. Further research has to be done, taking into account the weak empirical research on the core relationships between Generation Y, altruistic help and blood donation. The presented assumptions and the framework may help us, however, to understand the behaviour of Generation $\mathrm{Y}$ in terms of altruistic behaviour in general and their attitude to blood donation in particular.

This brings us back to the Darwiportunistic scenario: members of Generation Y donate blood on an altruistic basis, but also for their own 'well-being'. They are altruistic and opportunistic at the same time. Therefore, we have to look at the market situation: Generation Y might donate blood voluntarily, but might also support other projects. Those who are looking for donors have to offer Generation Y something in return: this is at least the feeling of being able to act altruistically, even for their own good.

\section{Disclosure}

The author declared no conflict of interest.

\section{References}

1 Fernández-Montoya A: Altruism and payment in blood donation. Transfus Sci 1997;18:379-386.

2 Keown J: The gift of blood in Europe: An ethica defence of EC directive 89/381. J Med Ethics 1997 23:96-100.

3 McLachlan HV: The unpaid donation of blood and altruism: A comment on Keown. J Med Ethics 1998;24:252-254.

4 Keown J: Debate: A reply to McLachlan. J Med Ethics 1998;24:255-256.

5 McLachlan HV: Altruism, blood donation and public policy: A reply to Keown. J Med Ethics 1999;25: 532-536.

6 Henseler O, Heiden M, Haschberger B, Hesse J, Seitz R: Bericht zur Meldung nach § 21 TFG für das Jahr 2007. Bundesgesundheitsblatt 2009;52: 715-731.

7 Schiefer G: Motive des Blutspendens. Eine tiefenpsychologische Untersuchung mit Gestaltungsoptionen für das Marketing von Nonprofit-Organisationen des Blutspendewesens, Wiesbaden, Deutscher Universitätsverlag, 2006, p 96.

8 Coupland D: Generation X: Tales for an Accelerated Culture. New York, St. Martin's Press, 1991.

$\checkmark$ Dries N, Pepermans R, De Kerpel E: Exploring four generations' beliefs about career. Is 'satisfied' the new 'successful'? J Managerial Psychol 2008;23: 907-928.
10 Reed C: Generation Y research: What makes ' $Y$ ' tick. Brand Strategy; February 2007:38-39.

11 Broadbridge AM, Maxwell GA, Ogden AM: Students' view of retail employment - key findings from Generation Y. Int J Retail Distribut Managem 2007;35:982-992.

12 Scholz C: Darwiportunismus: Das neue Szenario im Berufsleben. WISU 1999;28:1182-1184.

13 Darwin CR: The Origin of Species, ed 6. London, Murray, 1872.

14 Scholz C: Spieler ohne Stammplatzgarantie. Darwiportunismus in der neuen Arbeitswelt, Weinheim, Wiley-VCH, 2003.

15 Terjesen S, Frey R-V: Attracting and retaining Generation Y knowledge worker talent; in Vaiman V, Vance CM (eds): Smart Talent Management. Building Knowledge Assets for Competitive Advantage, Northampton, Edward Elgar, 2008, pp 66-92.

16 Rushton JP, Sorrentino RM: Altruism and helping behavior: an historical perspective; in Rushton JP, Sorrentino RM (eds): Altruism and Helping Behavior: Social, Personality, and Developmental Perspectives. Hillsdale, Erlbaum, 1981, pp 3-16.

17 Ridley M, Dawkins R: The natural selection of altruism; in Rushton JP, Sorrentino RM (eds): Altruism and Helping Behavior: Social, Personality, and Developmental Perspectives. Hillsdale, Erlbaum, 1981, pp 19-39.
18 Dawkins R: The Selfish Gene. Oxford, Oxford University Press, 1976.

19 Batson CD, Coke JS: Empathy: a source of altruistic motivation for helping?; in Rushton JP, Sorrentino RM (eds): Altruism and Helping Behavior: Social, Personality, and Developmental Perspectives. Hillsdale, Erlbaum, 1981, pp 167-187.

20 Wildman J, Hollingsworth B: Blood donation and the nature of altruism. J Health Econ 2009;28:492503.

21 Weinberg I, Zarka S, Levy Y, Shinar E: Why would young people donate blood? A survey-based questionnaire study. Vox Sang 2009;96:128-132.

22 Kitcher P: The evolution of human altruism. J Philosophy 1993;90:497-516.

23 Bowles S: Group competition, reproductive leveling, and the evolution of human altruism. Science 2006:314:1569-1572.

24 Roberts L: Time is money; Younger generations lend a hand in their own way. The New York Times Online 2006, November 13. http://query. nytimes.com/gst/fullpage.html?res $=9 \mathrm{~A} 05 \mathrm{E}$ 4DA163EF930A25752C1A9609C8B63 and $\mathrm{sec}=$ and spon $=$ and pagewanted $=2$.

25 Reisenwitz TH, Iyer R: Differences in Generation $\mathrm{X}$ and Generation Y: implications for the organization and marketers. Marketing Managem J 2009:19:91-103. 
26 World Health Organization: Blood Transfusion Safety. Report: Facts and Figures from the WHO Global Database on Blood Safety 1997-1999, 2001.

27 Lemmens KPH, Abraham C, Hoekstra T, Ruiter RAC, DeKort WLAM, Hrug J, Schaalma HP: Why don't young people volunteer to give blood? An investigation of the correlates of donation intentions among young nondonors. Transfusion 2005;45:945955 .

28 Windley JO: Young Blood: Persuading young people to give blood by applying concepts of self-perception and social norms theories to recruitment ads. Working paper August 2006. https://mospace. umsystem.edu/xmlui/bitstream/handle/10355/4531/ research.pdf? sequence $=3$.

29 Png IPL: Altruism and crowding out in the provision of public goods: cross-country evidence from blood donations (June 2008). Available at SSRN http://ssrn.com/abstract $=114372$.

30 Buyx AM: Blood donation, payment, and non-cash incentives: classical questions drawing renewed interest. Transfus Med Hemother 2009;36:329-339.

31 Healy K: Altruism and the Market for Human Blood and Organs. Chicago, The University of Chicago Press, 2006 